\title{
RELATIONSHIPS BETWEEN 16-18-YEAR-OLD STUDENTS' PARTICIPATION IN EXTRACURRICULAR ACTIVITIES AND THEIR PRO-SOCIAL BEHAVIOUR AS WELL AS THEIR VALUE ORIENTATIONS
}

Lina Baltakienè

\author{
Lithuanian Sports University, Kaunas, Lithuania
}

\begin{abstract}
Research background and hypothesis. Extra-curricular activities are concurrent with personality development, often named as assumption to pro-social behaviour and analysed considering value orientation. The following hypothesis was set in the study: indexes of expression of pro-social behaviour and value orientation were more characteristic of students involved in extra-curricular activities in comparison with non-active (after school) students. Type of extra-curricular activities was included in the analysis.

Research aim. The aim of the study was to analyse relationships between students' participation in extracurricular activities and expression of pro-social behaviour as well as their value orientation.

Research methods. The sample consisted of 179 students (82 girls and 97 boys) at the age of 16-18 years. Written survey was applied for the research. The participants completed the Pro-social Tendencies Measure (Carlo et al., 2003) and S. H. Schwartz's (1992) value orientation methodology. Participation in extra-curricular activities was assessed by asking question with a detailed list of structured activities.

Research results. Results of the study revealed that there were no links between students' participation in extra-curricular activities and pro-social behaviour. However, it was determined that public assistance was more characteristic of students participating in artistic extra-curricular activities in comparison to students that attended sports activities after school. The same situation was with value orientation: there was absence of correlations between students' participation in extra-curricular activities and value orientation, but significant differences related to the type of extra-curricular activities were found. Self-transcendence was more important to students that attended artistic extra-curricular activities in comparison with students participating in sports activities after school.

Discussion and conclusion. Tendencies of results of this research are comparable to those in other scientific studies. Studies that examined participation in extra-curricular activities and value orientations of interfaces in Lithuania are still missing.
\end{abstract}

Keywords: value orientation, students' participation in extra-curricular activities, pro-social behaviour.

\section{INTRODUCTION}

$\mathrm{C}$ urrently, the Lithuanian education system pays great attention to the development of extra-curricular activities to increase its diversity and to assure quality. Extra-curricular activities are identified as very important area of occupation of pupils which gives possibilities to unfold their talents, to deepen and to use practical knowledge acquired in the classroom (Popamokines veiklos veiksmingumas [Effectiveness of extracurricular activities], 2003). After-school activities are also an integral part of the student's personality development which strengthens their independence, creativity, initiative, citizenship, imagination and communication skills (Sprindžiūnas, 2002; Barkauskaitè, 2004). 
Participation in extra-curricular activities is particularly important in adolescence. This period is very important and full of changes, especially the middle adolescence. The Lithuanian education system includes all students of 9-12th grades to this age period (Šarakauskienè, Bagdonas, 2010). Teenagers can make independent decisions how to spend their time after school and these self-selected decisions of extracurricular activities may have important implications for their future trajectories. Participation in maintained and organized extracurricular activities may have a positive effect the formation of the sense of responsibility, clear articulation of life goals and orientation to their achievements and behavior in everyday situations (Cooper et al., 1999; Mahoney, Stattin, 2000; Feldman, Matjasko 2005). Extra-curricular activities are emphasized as an important factor in social skills formation and development (Burton, Marshall, 2005).

Positive, constructive and useful behaviour is defined as pro-social behavior and anti-social behavior is the opposite (Myers, 2000). According to S. Sukys (2010), our behavior depends on the perception of the situation and accepted decisions of behavior. Therefore, there are several forms of pro-social behavior, depending on the situation: public pro-social behavior (help when others see), anonymous pro-social behavior (the helper remains unknown), assistance in critical situation (when someone is injured and needs help), help in emotional situations (when someone cries), altruistic behavior and response to request for help (helping someone who asks for help). Participation in after-school activities leads to the increase of social understanding which is associated with selfunderstanding and pro-social behavior (Bosacki, 2003).

Firstly, pro-social behavior is fostered in families and their environment. A person can foster factors that stimulate pro-social behavior by himself, too. S. H. Schwartz (1992) claims that personal values are "criteria used by people when selecting and justifying actions and evaluating themselves, people and events" (p. 3). Recently, more and more attention is paid to spiritual development of young people and development of personality that is wellrounded, spiritually mature and capable of critical thinking. In the Concept of Lithuanian Education and the National Education Strategy of 2003-2012, the most important educational goal was raised: to help to foster human values and to fill out life with them. In general programmes and educational standards the defined goal is to set conditions for students to foster their valuable views.

Values are desirable goals or leading life principles of a person and they have different meanings for a particular individual. Values are socially supported and may be distinguished according to the consequences of participation in after-school activities (Imbrasiene, 2004). However, more often they are mentioned as preconditions of participation in extra-curricular activities and prosocial behavior.

To sum up, insights of different researchers are presented in this study which aims at establishing participation links with he expression of pro-social behaviour and value orientations of 16-18-year-old students who participate in after-school activities. The main hypothesis of the research is: students who participate in after-school activities tend to have higher pro-social and life value scores compared to those who do not participate in such activities. Study of children's behavioural expression of social life and value orientations draws attention not only to the extra-curricular activities, but also to the nature of this action. It is, therefore, likely that the social life behaviour and values scores will vary depending on the nature of extracurricular activities.

\section{RESEARCH METHODS}

Research subjects. The sample consisted of 179 students group ( 82 girls and 97 boys) aged 1618 years. Students were selected using convenient and purposive sampling methods. They were taken from Kaunas city schools and extracurricular educational institutions. Using convenient sampling method, students were selected from Kaunas secondary schools. Using purposive sampling method, students were selected from extracurricular educational institutions. Purposive selection was applied additionally because the aim was to include pupils who regularly attend certain after-school activities. Thus, the study emphasizes not the size of samples, but rather the selection of specific subjects required by the study aim.

Research methods. Method of written survey was applied, subjects were given questionnaires. One part of the questionnaire was designed for socio-demographic characteristics of students (gender, class, family composition, parents' emigration to work in a foreign country), the other part of the questionnaire was related to problematic 
questions. The study purpose was introduced in questionnaire instructions. The institution carrying out the research was indicated as well. The order of questionnaire answers was explained and it was mentioned that the survey was anonymous. In order to ensure the anonymity of respondents, the schoolchildren were asked not to indicate their personal data, school and class. Although the latter data can be identified, it is not used in this study.

Studying pro-social behaviour of students, pro-social behaviour assessment scale was used (PTM-R) (Carlo et al., 2003) which had already been applied in research with Lithuanian students (Šukys, 2010). The scale consists of 21 statements. Assessing every statement the participants had to choose one of five options ( $1-$ it is uncommon to me and 5 - typical of me). In the original scale six social life forms of pro-behaviour are identified: public assistance to others (3 statements), support in emotional situations (five statements), assistance in a disaster (3 statements), anonymous support (4 statements), altruistic behaviour (4 statements) and help when asking for it (2 statements). After factor analysis (that was performed for this research data), four factors were identified: Factor I - helping others in distress and asking for help (Cronbach's alpha - 0.80), Factor II - anonymous support (Cronbach's alpha - 0.71), Factor III altruistic behaviour (Cronbach's alpha - 0.55) and Factor IV - public assistance to others (Cronbach's alpha - 0.86). Internal coherence of all scale is Cronbach's alpha score of 0.78 .

S. H. Schwartz's value methodology was used to determine pupils' value orientations. Students were given a list of 48 values, each of which had to be valued according to how important it was to them (from 1 to 9, where 1 - is adverse to the principles of my life, 9 - this is very important to me). S. H. Schwartz (1992) reported that participants who equally (by assigning the same score) assessed more than $62.5 \%$ of the listed values or who rated more than $37.5 \%$ of the listed values by 9 points (this was the maximum possible score) did not put any serious efforts to distinguish the relative importance of their values, and they had to be eliminated from the analysis. To get as accurate results as possible, this provision was applied for this research, too. Therefore, 30 respondents were eliminated from the research. Looking further, the data analysis was based on 179 questionnaires (209 questionnaires were collected in total). As the abovementioned methodology of values had been applied in several studies in Lithuania (Butkevičienè et al., 2009), additional scale factor analysis was not done. In data analysis, four types of classification of higher values were used (Schwartz, 1992): self-transcendence (Cronbach's alpha - 0.77), conservatism (Cronbach's alpha 0.65), emphasis on self (Cronbach's alpha - 0.67), openness to change (Cronbach's alpha - 0.78).

Students' participation in extra-curricular activities was determined by asking a question with possible alternatives. Students could choose the activities they attended or to indicate other unmentioned clubs that they attended. Based on their responses, the students were divided into groups of those who participated in extracurricular activities $(n=142,79.3 \%)$ and those who did not $(\mathrm{n}=37,20.7 \%)$. Those who participated in extra-curricular activities were divided into groups according to the extracurricular activity type: attending only sports groups $(n=54,38 \%)$, attending only clubs related to artistic activities $(\mathrm{n}=60,42.3 \%)$, attending science clubs $(\mathrm{n}=9$, $6.3 \%$ ), and attending a number of several different clubs $(\mathrm{n}=19,13.4 \%)$. Some types of activities were attended by fewer students, therefore, when analyzing the data according to extracurricular activity type, two groups could be distinguished: pupils who attended sports clubs only and pupils who attended art clubs only. Types of these clubs are different according to their goals and activities.

Procedure of the reseach. The study was conducted in 2011, in May and October. The survey was coordinated with Kaunas city Department of Education and school administrators. After agreement on the survey time, researchers went to schools. The survey took place in the classrooms during the lessons. School teachers or the psychologist participated during the survey. Before each survey the students were explained the research purpose and filling instructions, the study emphasized anonymity and opportunity to refuse to participate in the survey.

Statistical analysis. The data were processed using SPSS 16.0 software. Cronbach's alpha reliability coefficient was used to check the reliability of scales as well as their internal consistency, factor analysis was used to ground the structure of scales. The analysis of variance showed that distribution of all variables had statistically significant distance from the normal distribution, therefore, non-parametric criterion was chosen for further analysis (Vaitkevičius, Saudargienè, 2006). 
Descriptive statistics were used for the description of participants and general trends of the analyzed phenomena, for differences between the two treatment groups - Mann Whitney criterion. The chosen level of significance was $\alpha=0.05$.

\section{RESEARCH RESULTS}

Firstly, an overview of data of students' participation in extra-curricular activities was performed. The results showed that 63.0 per cents of students were involved in extra-curricular activities (Table 1). Students preferred sports and artistic clubs. 10.6 per cent of students attended several different clubs at the same time. However, sports clubs were more popular among boys and art clubs - among girls. Besides, girls attended several different clubs more often than boys. Technical type clubs were not popular among the analysed students. Thirty seven students stated that they had not participated in any extra-curricular activities, but they formed only one fifth of the subjects in our sample.
Gender-based differences of pro-social behavior and value orientation were not identified, therefore, in further analysis they are not discussed.

Although the expression of pro-social behaviour did not differ in groups of pupils who attended or did not attend after-school activities, statistically significant differences were observed when evaluating the groups of those who attended different clubs (Table 2). Students who participated in artistic type clubs showed more public assistance compared to students who were athletes.

There were no statistically significant differences of individual values comparing students who attended after-school activities and who did not. However, a tendency was observed in the differences of self-transcendence values among students who attended different type clubs (Table 3). That is, self-transcendence values were more important to students who attended artistic clubs compared with the athletes.

\begin{tabular}{|l|c|c|c|}
\hline \multicolumn{1}{|c|}{ Activity type } & $\begin{array}{c}\text { Girls } \\
(\mathbf{n = 8 2})\end{array}$ & $\begin{array}{c}\text { Boys } \\
(\mathbf{n = 9 7 )}\end{array}$ & $\begin{array}{c}\text { In total } \\
(\mathbf{n}=\mathbf{1 7 9})\end{array}$ \\
\hline Sports clubs & $13(7.3 \%)$ & $41(22.9 \%)$ & $54(30.2 \%)$ \\
\hline Artistic type clubs & $41(22.9 \%)$ & $19(10.6 \%)$ & $60(33.5 \%)$ \\
\hline Technical type clubs & $3(1.7 \%)$ & $6(3.3 \%)$ & $9(5.0 \%)$ \\
\hline Participate in extra-curricular activities & $13(7.3 \%)$ & $6(3.3 \%)$ & $25(10.6 \%)$ \\
\hline $\begin{array}{l}\text { Do not participate in extra-curricular } \\
\text { activities }\end{array}$ & $12(6.7 \%)$ & $25(14 \%)$ & $37(20.7 \%)$ \\
\hline
\end{tabular}

Table 1. Distribution of pupils according to their participation in extra-curricular activities

Table 2. Differences in the expression of pro-social behaviour components according to participation in extra-curricular activity and its type

\begin{tabular}{|c|c|c|c|c|c|c|}
\hline \multirow{3}{*}{$\begin{array}{c}\text { Groups of } \\
\text { pro-social behavior }\end{array}$} & \multicolumn{2}{|c|}{$\begin{array}{c}\text { Participation in extra-curricular } \\
\text { activities }\end{array}$} & \multirow[b]{2}{*}{$\begin{array}{c}\text { Mann } \\
\text { Whitney U }\end{array}$} & \multicolumn{2}{|c|}{$\begin{array}{c}\text { Participation in extra-curricular } \\
\text { activities }\end{array}$} & \multirow[b]{2}{*}{$\begin{array}{c}\text { Mann } \\
\text { Whitney U }\end{array}$} \\
\hline & $\begin{array}{c}\text { Do not } \\
\text { participate in } \\
\text { extra-curricular } \\
\text { activities }\end{array}$ & $\begin{array}{c}\text { Participate in } \\
\text { extra-curricular } \\
\text { activities }\end{array}$ & & $\begin{array}{c}\text { Attend sports } \\
\text { clubs }\end{array}$ & $\begin{array}{l}\text { Attend artistic } \\
\text { clubs }\end{array}$ & \\
\hline & Mean (SD) & Mean (SD) & & Mean (SD) & Mean (SD) & \\
\hline Anonymous support & $2.7(1.0)$ & $2.6(1.0)$ & 2376.5 & $2.5(1.0)$ & $2.7(1.0)$ & 1395.5 \\
\hline $\begin{array}{l}\text { Public assistance to } \\
\text { others }\end{array}$ & $3.0(1.0)$ & $3.0(0.9)$ & 2592.5 & $2.7(0.7)$ & $3.1(1.0)$ & $1250.5 *$ \\
\hline Altruistic behaviour & $2.8(0.9)$ & $2.9(0.9)$ & 2537.0 & $2.8(0.8)$ & $2.9(0.9)$ & 1609.0 \\
\hline $\begin{array}{l}\text { Help others in case } \\
\text { of emergency and } \\
\text { when others ask for } \\
\text { help }\end{array}$ & $3.6(0.8)$ & $3.5(0.8)$ & 2404.5 & $3.4(0.7)$ & $3.6(0.8)$ & 1309.0 \\
\hline
\end{tabular}

Note. $*-p<0.05$. 
Table 3. Differences in the importance of higher range values groups according to participation in extra-curricular activity and its type

\begin{tabular}{|c|c|c|c|c|c|c|}
\hline \multirow{3}{*}{ Value types/groups } & \multicolumn{2}{|c|}{$\begin{array}{c}\text { Participation in extra-curricular } \\
\text { activities }\end{array}$} & \multirow[b]{2}{*}{$\begin{array}{c}\text { Mann } \\
\text { Whitney U }\end{array}$} & \multicolumn{2}{|c|}{$\begin{array}{c}\text { Participation in extra-curricular } \\
\text { activities }\end{array}$} & \multirow[b]{2}{*}{$\begin{array}{c}\text { Mann } \\
\text { Whitney U }\end{array}$} \\
\hline & $\begin{array}{c}\text { Do not } \\
\text { participate in } \\
\text { extra-curricular } \\
\text { activities }\end{array}$ & $\begin{array}{c}\text { Participate in } \\
\text { extra-curricular } \\
\text { activities }\end{array}$ & & $\begin{array}{l}\text { Attend sports } \\
\text { clubs }\end{array}$ & $\begin{array}{l}\text { Attend artistic } \\
\text { clubs }\end{array}$ & \\
\hline & Mean (SD) & Mean (SD) & & Mean (SD) & Mean (SD) & \\
\hline Self-transcendence & $6.9(1.1)$ & $6.9(1.2)$ & 2593.0 & $6.6(1.4)$ & $7.1(0.9)$ & $1308.5 \#$ \\
\hline Conservatism & $6.7(1.1)$ & $6.5(1.2)$ & 2430.0 & $6.5(1.4)$ & $6.6(1.0)$ & 1544.0 \\
\hline Emphasis on self & $6.5(1.0)$ & $6.5(1.2)$ & 2551.0 & $6.5(1.3)$ & $6.5(1.1)$ & 1575.5 \\
\hline Openness to change & $7.1(1.2)$ & $7.2(1.3)$ & 2490.5 & $7.0(1.4)$ & $7.3(1.1)$ & 1425.5 \\
\hline
\end{tabular}

Note. $\#-\mathrm{p}<0.1$.

\section{DISCUSSION}

The obtained study results about students' participation in extra-curricular activities overlapped with the results of other researchers (Dzenuškaitė1991; Barkauskaitė, 2004; Šukys, 2010): the most popular extra-curricular activities remained various sports clubs, less popular - art clubs. Similarly, it was noticed that sports clubs were more popular among boys, artistic clubs among girls. However, after conducted study, S. Dzenuškaitè (1991) concluded that choices of clubs among girls and boys were similar.

When analysing the links of students' participation in extra-curricular activities with the expression of pro-social behaviour and value orientations it was not established that prosocial behaviour is was more typical for of those who participated in extra-curricular activities than those who did not. Most authors (Cooper et al., 1999; Mahoney, Stattin, 2000; Feldman, Matjasko, 2005; Šukys, 2010) argue that extracurricular activities have a positive impact on pupil's behaviour. J. Cooper, the co-authors (1999), found that students who attended extra-curricular activities demonstrated better learning outcomes, a stronger sense of responsibility, clear life goals and their trajectories of achievements.

Data analysis revealed links between students' chosen type of extra-curricular activity and expression of their pro-social behaviour. It was found that provision of public assistance/help was more common for students of in artistic clubs rather than for those who attended sports clubs. The findings conflict with Lithuanian authors' (Šukys, 2010) results of research. According to S. Šukys (2010), students who participate in sports groups tend to have hedonistic motives: they are more likely to do that when they get approval or that is related to self-interest and they get benefits for themselves. However, foreign researchers (Hansen et al., 2003; Larson et al., 2006) found that students who attended artistic groups tended to behave more pro-socially. G. Carlo et al. (2002) divided prosocial behaviour into altruistic (voluntary helping motivated primarily by the concern for the needs and welfare of another), public (in front of others and self-interested), anonymous (tendency to help others without other people's knowledge), dire (helping others in emergency or crisis situations), emotional (behaviours intended to benefit others enacted under emotionally evocative situations), and compliant (helping others when asked) behaviour. In addition, foreign literature indicates that participation in sports clubs may have not only a positive impact, such as the development of initiative, but also a negative experience, such as stress and use of alcohol (Scanlan et al. 2005; Larson et al., 2006).

The study revealed relations between the chosen type of after-school activities and students' value orientations. Self-transcendence values were more important to students who attended artistic clubs than to those who did sports. On the dimension of self-enhancement vs. self-transcendence, power and achievement values opposed universalism and benevolence values. The other dimension was openness to change vs. conservation. Here selfdirection and stimulation values opposed security, conformity and tradition values. Both of the former ones emphasized independent action, thought and feeling and readiness for new experience, whereas all of the latter ones emphasized self-restriction, 
order and resistance to change (Schwartz, 1992). Dedication to others is incompatible with the pursuit of victories in sport which is the aim of sports extra-curricular activities. Meanwhile, competition in artistic groups is not encouraged. However, further studies are needed for the investigation of the relations between the type of extracurricular activities and participating students' value orientations. In addition, too small sample size did not allow using more sophisticated techniques of statistical analysis which could lead to assumption of causality (values as assumptions or implications of extra-curricular activity analysis). Further studies of more diverse design are needed to determine causality.

\section{CONCLUSIONS AND PERSPECTIVES}

Results of the research, that took place in Kaunas city, did not reveal differences in the expression of pro-social behaviour and value orientation among students who participated in extra-curricular activities and who did not. The data analysis has revealed links between students' chosen type of extra-curricular activities and expression of prosocial behaviour, value orientation. It was found that public assistance to others and self-transcendence values were more characteristic of students who attended artistic clubs in comparison with athletes.

\section{REFERENCES}

Barkauskaite, M. (2004). Moksleiviu dorinis ugdymas popamokinèje veikloje. Pedagogika, 72, 20-25.

Bosacki, S. (2003). Psychological pragmatics in preadolescents: Sociomoral understanding, self-worth, and school behavior. Journal of Youth and Adolescence, $32,141-155$.

Burton, J. M., Marshall, L. A. (2005). Protective factors for youth considered at risk of criminal behaviour: Does participation in extracurricular activities help? Criminal Behaviour \& Mental Health, 15 (1), 46-64.

Butkevičienè, E., Vaidelytè, E., Žvaliauskas, G. (2009). Lyderystès raiška Lietuvos valstybès tarnyboje. Viešoji politika ir administravimas, 27, 36-44.

Carlo, G., Hausmann, A., Christiansen, S., Randall, A. (2003). Sociocognitive and behavioral correlates of a measure of prosocial tendencies for adolescents. Journal of Early Adolescence, 23 (1), 107-134.

Cooper, H., Valentine, J. C., Nye, B., Lindsay, J. J. (1999). Relationships between five after - school activities and academic achievement. Journal of Educational Psychology, 9, 369-378.

Dzenuškaite, S. (1991). Mokiniu nepamokinès veiklos tobulinimas. Vilnius: PMTI.

Feldman, A. F., Matjasko, J. L. (2005). The role of school-based extracurricular activities in adolescent development: A comprehensive review and future directions. Review of Educational Research, 75, $159-210$.

Hansen, D. M., Larson, R. W., Dworkin, J. B. (2003). What adolescents learn in organized youth activities: A survey of self-reported developmental experiences. Journal of Research on Adolescence, 13, 25-55.

Imbrasienè, J. (2004). Vertybinès orientacijos ir politinis dalyvavimas Lietuvoje: individualistinè-kolektyvinè dimensija. Filosofija. Sociologija, 2, 26-32.
Larson, R. W., Hansen, D. W., Moneta, G. (2006). Differing profiles of developmental experiences across type of organized youth activities. Developmental Psychology, 42, 849-863.

Mahoney, J. L., Stattin, H. (2000). Leisure activities and adolescent antisocial behavior: The role of structure and social context. Journal of Adolescence, 23 (2), 113-128. Myers, D. G. (2000). Psichologija. Kaunas: Poligrafija ir informatika.

Popamokinès veiklos veiksmingumas. (2003). VPU sociologiniu švietimo tyrimu laboratorijos tyrimu ataskaita [2012 04 09]. Internet link: <http://www.smm. 1t/svietimo_bukle/docs/tr_ataskaita_040303.doc>

Scanlan, T., Babkes, M., Scanlan, L. (2005). Participation in sports: A developmental glimpse at emotion. In J. Mahoney, J. Eccles, R. Larson (Eds.), Organized Activities as Contexts of Development (pp. 275-309). Mahwah, NJ: Erlbaum.

Schwartz, S. H. (1992). Universals in the content and structure of values: Theoretical advances and empirical tests in 20 countries. In M. P. Zanna (Ed.), Advances in Experimental Social Psychology. Academic Press, 25, $1-65$.

Sprindžiūnas, A. (2002). Aukštesniujų klasių moksleivių santykis su veikla kaip ju tolerancijos raidos prielaida. Acta Paedagogica Vilnensia, 9, 173-181.

Šarakauskienè, Ž., Bagdonas, A. (2010). Vyresniujuc klasių mokinių subjektyvios gerovès komponentu ir sociodemografinių komponentų sąsajos. Psichologija, $41,18-32$.

Šukys, S. (2010). Dalyvavimo popamokinëje veikloje sąsajos su mokiniu prosocialaus elgesio raiška. Ugdymas. Kūno kultūra. Sportas, 4 (79), 77-85.

Vaitkevičius, R., Saudargienè, A. (2006). Statistika su SPSS psichologiniuose tyrimuose. Kaunas: VDU leidykla. 


\title{
16-18 METŲ MOKSLEIVIŲ DALYVAVIMO POPAMOKINĖJE VEIKLOJE SĄSAJOS SU JŲ VERTYBËMIS IR PROSOCIALIU ELGESIU
}

\author{
Lina Baltakienè \\ Lietuvos sporto universitetas, Kaunas, Lietuva
}

\begin{abstract}
SANTRAUKA
Tyrimo pagrindimas ir hipotezé. Popamokinè veikla yra neatsiejama moksleivio asmenybès ugdymo dalis, dažnai ịvardijama kaip prosocialaus elgesio prielaida ir analizuojama atsižvelgiant $i$ joje dalyvaujančiuju vertybines orientacijas. Daroma prielaida, kad popamokinèje veikloje dalyvaujantiems moksleiviams būdingi aukštesni prosocialaus elgesio išreikštumo ir vertybių svarbos rodikliai, lyginant su nedalyvaujančiais šioje veikloje. I analizę itraukiamas ir popamokinès veiklos pobūdis.

Tikslas - išsiaiškinti 16-18 metų moksleivių dalyvavimo popamokinėje veikloje sąsajas su jų prosocialaus elgesio raiška ir vertybinèmis orientacijomis.

Metodai. Tiriamuju imti sudare 179 moksleiviu grupè (82 mergaitès ir 97 berniukai), kuriu amžius 16-18 metú. Tiriant moksleivius taikytas apklausos raštu metodas, kurį sudare socialinė-demografinè ir diagnostinè dalys. Moksleivių prosocialus elgesys tirtas naudojant Prosocialaus elgesio vertinimo skalę (Carlo ir kt., 2003). Vertybinèms orientacijoms nustatyti pasirinkta S. H. Schwartz (1992) metodika. Moksleivių dalyvavimas popamokinejje veikloje nustatytas pateikiant apie tai klausimą su galimomis alternatyvomis.

Rezultatai. Tyrimo rezultatai neatskleidè moksleiviu dalyvavimo popamokineje veikloje ir prosocialaus elgesio raiškos sąsajų. Analizuojant tyrimo duomenis buvo atskleistos sąsajos tarp moksleivių pasirinktos popamokinès veiklos pakraipos ir ju prosocialaus elgesio raiškos. Nustatyta, kad meninès veiklos būrelius lankantiems moksleiviams būdingesnis viešosios pagalbos teikimas, palyginus su sportuojančiais. Vertybinès orientacijos taip pat statistiškai reikšmingai nesiskyrè popamokinę veiklą lankančių ir nelankančių moksleiviu grupėse. Tyrimas atskleidè dalyvavimo pasirinktos popamokinès veiklos pakraipos sąsajas su moksleivių vertybinemmis orientacijomis. Meninès veiklos būrelius lankantiems moksleiviams būdingesnès savitranscendencijos vertybės nei sportuojantiems.

Aptarimas ir išvados. Pastebètos dalyvavimo konkrečioje popamokinëje veikloje ir prosocialaus elgesio sąsaju tendencijos panašios į kitų tyrejju gautus rezultatus. Tyrimų, kurie nagrinètų dalyvavimo popamokinèje veikloje ir vertybinių orientacijų sąsajas Lietuvoje vis dar trūksta.
\end{abstract}

Raktažodžiai: vertybinès orientacijos, moksleivių dalyvavimas popamokinėje veikloje, prosocialus elgesys.

Gauta 2012 m. spalio 8 d.

Received on October 8, 2012 